\title{
Intellectual Capital dan Ukuran Fundamental Kinerja Keuangan Perusahaan
}

\author{
Ceicilia Bintang Hari Yudhanti ${ }^{1}$ dan Josepha C. Shanti ${ }^{2}$ \\ 1,2\} Fakultas Bisnis Universitas Katolik Widya Mandala Surabaya \\ Email: bintanghariyudhanti@yahoo.co.id
}

\begin{abstract}
ABSTRAK
Penelitian ini bertujuan untuk menguji pengaruh antara ukuran intellectual capital dan ukuran fundamental kinerja keuangan perusahaan. Penelitian ini juga menggunakan beberapa variabel kontrol yaitu size dan jenis industri. Sampel yang digunakan dalam penelitian ini adalah jenis perusahaan yang secara intensif menggunakan modal intelektual yaitu industri jasa. Hipotesis dalam penelitian ini diuji menggunakan regresi berganda. Intellectual capital pada perusahaan jenis industri jasa menunjukkan adanya pengaruh terhadap kinerja keuangan perusahaan. Ukuran eksternal perusahaan digunakan pada penelitian ini untuk mengukur intellectual capital yaitu market-to-book value. Pasar merespon kinerja perusahaan yaitu profitability dan produktivitas perusahaan yang diproksikan oleh EBIT dan asset turnover.
\end{abstract}

Kata kunci: Intellectual capital, ukuran fundamental, kinerja keuangan perusahaan.

\begin{abstract}
This study aims to examine the effect of intellectual capital and the fundamental measurements of company financial performance. This study also used several control variables, namely size and type of industry. Samples used in this study is the type of company that intensively used the intellectual capital, that is the service industry. The hypothesis are tested using multiple regression. Intellectual capital in the service industry showed the influence to the company's financial performance. External size of the companies used to measure the intellectual capital is market-to-book value. Market responds to the company's profitability and company's productivity.
\end{abstract}

Keywords: Intellectual capital, fundamental measurement, company financial performance.

\section{PENDAHULUAN}

Teori intellectual capital telah banyak dikembangkan melalui gagasan-gagasan dan pemikiranpemikiran para praktisi. Saat ini, teori tersebut merupakan petunjuk untuk mengelola aset tak berwujud dan memfasilitasai kesuksesan melalui keuntungan persaingan yang berkelanjutan untuk memimpin perusahaan dan organisasi. Para praktisi menganggap aset tak berwujud merupakan faktor yang menentukan kesuksesan perusahaan. Pengembangan teori di bidang intellectual capital didasarkan pada penelitian antar disiplin ilmu. Untuk memahami penciptaan nilai organisasi, perlu memperhatikan aset tak berwujud dan intellectual capital sebagai perbedaan jenis-jenis pengetahuan dan untuk mencapai pengetahuan yang ada dalam bentuk yang berbeda dan operasional yang berbeda.

Zéghal dan Maaloul (2010) menyatakan bahwa mengukur intellectual capital sulit karena bersifat tak berwujud dan non fisik. Model akuntansi tradisional yang dikandung dalam operasi perusahaan dalam suatu ekonomi industrial tetap fokus pada aset keuangan dan fisik dan mengabaikan aset intellectual capital. Stewart (1997) mendefinsikan intellectual capital sebagai total saham atas kolektif pengetahuan, informasi, teknologi, hak properti intelektual, pengalaman, pembelajaran organisasi dan kompetensi, sistem komunikasi tim, hubungan pelanggan, dan merek yang mampu untuk menciptakan nilai perusahaan. 
Intellectual capital pada level organisasi muncul dari proses dimana level pengetahuan individual, bertindak sebagai komponen dengan mekanisme struktural dalam bentuk komunikasi dan lingkungan, yang terdapat pada perangkat struktural organisasi yang berinteraksi untuk mencapai tingkatan yang lebih tinggi. Manusia saat ini menjadi pusat perhatian karena berkaitan dengan peningkatan pengembangan ilmu ekonomi dan sosiologi. Para ahli dibidang ini menyepakati bahwa modal manusia memiliki peran penting atau bahkan lebih penting daripada faktor teknologi dalam menjalankan pertumbuhan ekonomi. Pendidikan adalah salah satu cara untuk meningkatkan modal manusia.

Di dalam perspektif ekonomik, peningkatan pertumbuhan ekonomik menunjuk pada ekonomik berbasis pengetahuan dan pengimplementasian manajemen pengetahuan. Sistem ini membagi opini modal secara konvensional seperti sumber daya alam, sumber daya keuangan, dan sumber daya aset berwujud yang kurang berarti tanpa modal berbasis pengetahuan dan modal berbasis teknologi. Pengimplementasian modal berbasis pengetahuan dan teknologi akan mengaselerasi keefisienan dan keefektifan implementasi sumber daya lain sehingga sumber daya tersebut dapat mempengaruhi keuntungan perusahaan secara kompetitif.

Chen, Cheng dan Hwang (2005) menguji pengaruh intellectual capital perusahaan terhadap nilai pasar dan kinerja keuangan dan kemungkinan sebagai indikator untuk kinerja keuangan masa depan dengan menggunakan perusahaan yang listing di Taiwan. Zerenler, Hasiloglu dan Sezgin (2008) menginvestigasi pengaruh intellectual capital industri suplier otomotif Turki terhadap inovasi kinerja perusahaan. Rehman, Illyas dan Rahman (2011) menguji kinerja intellectual capital di sektor asuransi untuk tahun 2009. Perusahaan sektor ini mengindikasikan bahwa intellectual capital menentukan kualitas jasa perusahaan yang akan diberikan ke pelanggan.

Kinerja perusahaan sering digunakan oleh berbagai pihak seperti stakeholder, akademisi dan pembuat kebijakan. Kinerja perusahaan menggambarkan berbagai bagian dari keseluruhan perusahaan dari sisi keuangan itu sendiri ke level output hingga tingkat pengembalian pasar. Sedangkan kinerja keuangan perusahaan memberikan informasi penting untuk memprediksi kemampuan/ kapasitas perusahaan dalam menghasilkan profitabilitas dari sumber daya yang dimiliki.

Ukuran fundamental perusahaan dapat digunakan untuk mengukur kinerja keuangan perusahaan. Penelitian ini bertujuan untuk menguji pengaruh ukuran intellectual capital terhadap kinerja keuangan perusahaan yang menggunakan profitabilitas dan produktivitas. Sampel yang akan digunakan dalam penelitian ini adalah jenis perusahaan yang secara insentif menggunakan modal intelektual. Industri jasa memerlukan banyak tenaga kerja dalam menjalan aktivitas perusahaan. Tenaga kerja juga dituntut untuk memiliki pengetahuan, informasi dan wawasan yang mendalam tentang perusahaan dan produk perusahaan agar dapat menawarkan dan meyakinkan konsumen untuk membeli jasa perusahaan. Berdasarkan latar belakang diatas maka perumusan masalah penelitian ini adalah Apakah intellectual capital yang menggunakan ukuran eksternal perusahaan mempengaruhi kinerja keuangan perusahaan yang mengintensifkan modal manusia? Penelitian ini bertujuan untuk menguji pengaruh intellectual capital terhadap kinerja keuangan perusahaan.

\section{Pengertian Intellectual Capital}

Intellectual capital adalah salah satu strategik aset yang penting dalam pengetahuan berbasis ekonomi (Rehman et al. (2011). Terdapat beberapa definisi intellectual capital sejak awal, dalam kenyataan baik pengetahuan dan ekonomik berdasarkan pendekatan-pendekatan yang ada (Rehman et al. (2011). Pengetahuan ekonomik adalah dimana produksi dan distribusi dengan menggunakan pengetahuan adalah suatu kekuatan utama untuk menciptakan pertumbuhan dan kesejahteraan yang didefinisikan oleh The Organization for Economic Co-operation and Development (OECD 1996). Kemampuan intelektual manusia adalah suatu kunci intelektual dan strategi aset yang meningkatkan efisiensi perusahaan.

Zéghal dan Maaloul (2010) menyatakan bahwa saat ini beberapa perusahaan menginvestasikan dalam pelatihan karyawan, penelitian dan pengembangan, hubungan pelanggan, sistem komputer dan administrasi, dll. Investasi ini sering disebut sebagai intellectual capital yang bertumbuh dan bersaing dengan investasi modal fisik dan keuangan.

Bontis, N., Keow, W.C.C. dan Richardson, S. (2000) memberikan definisi intellectual capital dari berbagai ringkasan peneliti:

- Intellectual capital adalah sukar dipahami, tetapi sekali ditemukan dan diekploitasi maka kemungkinan akan memberikan suatu organisasi dengan sebuah sumber daya yang baru untuk bersaing dan menang (Bontis 1996).

- Intellectual capital adalah suatu bentuk untuk mengkombinasikan aset tak berwujud-pasar, properti intelektual, manusia dan infrastruktur yang memampukan perusahaan untuk menjalankan fungsi (Brooking, 1996). 
- Intellectual capital memasukkan seluruh proses dan aset yang bukan secara normal ditunjukkan dalan laporan posisi keuangan dan seluruh aset tak berwujud (merek dagang, paten dan merek) yang metode akuntansi modern mempertimbangkan memasukkan seluruh pengetahuan anggotanya dan mempraktekkan pengetahuannya (Roos et al., 1997).

- Intellectual capital adalah material intelektualpengetahuan, informasi, properti intelektual, pengalaman-yang dapat diambil untuk digunakan untuk menciptakan kesejahteraan. Intellectual capital adalah kekuatan otak kolektif yang memanfaatkan pengetahuan (Stewart 1997).

- Intellectual capital adalah pencarian penggunaan pengetahuan yang efektif (barang jadi) sebagai lawan untuk informasi (bahan baku baru) (Bontis 1998) dan

- Intellectual capital dianggap sebagai elemen nilai pasar perusahaan seperti halnya premium pasar (Olve et al., 1999).

Meningkatknya perbedaan antara nilai pasar dan nilai buku perusahaan dipertimbangkan sebagai konsep intellectual capital sebagai kunci proses penciptaan nilai (Martǐ 2003). Muncul kelompok jasa meningkatkan peran pengetahuan dan kreativitas karyawan dalam menambah nilai perusahaan. Usaha-usaha untuk mengkapitalisasi investasi perusahaan dalam bentuk orang di dalam Neraca gagal dilakukan karena masalah pengukuran. Subjek ini meningkat dengan cepat di era sembilanpuluhan dengan adanya pertumbuhan yang cepat di bidang teknologi informasi dan komunikasi. Pengetahuan menjadi kunci faktor produksi, bagaimanapun akun-akun keuangan masih didominasi oleh faktor-faktor produksi tradisional, termasuk bangunan dan mesin. Kemudian, penting sekali untu mengembangkan suatu pemahaman tentang modal pengetahuan.

Intellectual capital adalah suatu konsep yang sering membangi ke dalam kategori yang berbeda, dan paling umum digunakan yaitu manusia, hubungan dan struktur modal. Intellectual capital juga sering disebut sebagai intellectual property, intellectual assets, dan knowledge assets. Bagaimanapun konsep ini berbeda satu sama lain (McConnachie, 1997). Intellectual capital dipandang sebagai pengetahuan yang memiliki nilai potensial. Intellectual capital mengungkapkan transformasi pengetahuan sebagai suatu yang berharga di dalam perusahaan, sementara intellectual assets adalah perubahan bentuk dalam pengetahuan merubah produk. Marr and Schiuma (2001) menyatakan bahwa intellectual capital kelompok aset pengetahuan yang diatribusikan untuk sebuah organisasi dan yang paling signifikan dalam peningkatan posisi bersaing organisasi dengan penambahan nilai bagi stakeholders kunci yang teridentifikasi.

\section{Pengukuran Intellectual Capital}

Sistem akuntansi konvensional dikembangkan untuk ekonomi manufaktur dan mengukur nilai keuangan dan fisik aset berwujud dapat dikuantifikasikan. Aset tersebut meliputi plant, equipment, laboratories dan sumber daya alam, aset tersebut mudah diidentifikasi dan dapat terjual dengan harga kesepakatan. Bagi akuntan dan penyusuan standar akuntansi, masalah aset tak berwujud sulit untuk menghitung tingkat perubahan. Hal ini hampir tidak mungkin untuk menandingkan investasi dan beban dalam satu periode dengan laba di periode lainnya. Akuntansi konvensional mengatur aset berwujud seperti komputer, tanah dan bangunan-sebagai aset. Tetapi investasi aset tidak berwujud diatur sebagai biaya.

Perlakuan akuntansi intellectual capital masih menjadi dilema bagi para praktisi akuntansi maupun manajer perusahaan. Namun demikian ada banyak konsep pengukuran intellectual capital yang dikembangkan oleh para peneliti saat ini, metode yang dikembangkan tersebut dapat dikelompokkan kedalam dua kelompok yaitu pengukuran non monetary (non financial) dan pengukuran monetary (financial) (Hartono 2001).

Sveiby 1997 dalam Martĩ 2003 memberikan model yang representative dan pokok-pokok yang mendasari teori standar (paragidma yang berlaku) untuk intellectual capital:

Tabel 1. Intangible Assets Monitor

\begin{tabular}{|c|c|c|c|}
\hline \multirow[b]{2}{*}{ Equity } & \multicolumn{3}{|c|}{$\begin{array}{c}\text { Intangible Assets } \\
\text { (Stock Price Premiun) }\end{array}$} \\
\hline & $\begin{array}{l}\text { External } \\
\text { Structure }\end{array}$ & $\begin{array}{l}\text { Internal } \\
\text { Structure }\end{array}$ & $\begin{array}{l}\text { Individual } \\
\text { Comptence }\end{array}$ \\
\hline $\begin{array}{l}\text { (Book Value) } \\
\text { Tangible } \\
\text { Assets minus } \\
\text { visible debt }\end{array}$ & $\begin{array}{l}\text { (Brand, } \\
\text { customer and } \\
\text { supplier } \\
\text { relationship) }\end{array}$ & $\begin{array}{l}\text { (The } \\
\text { Organisation: } \\
\text { managemen, } \\
\text { legal } \\
\text { structure, } \\
\text { manual } \\
\text { systems, } \\
\text { attitude, R\&D, } \\
\text { software) }\end{array}$ & $\begin{array}{l}\text { (Education, } \\
\text { experience) }\end{array}$ \\
\hline
\end{tabular}

\section{Aset Kompetensi Individual}

Bagian ini menunjukkan untuk aset seperti pendidikan karyawan, pengalaman, pengetahuan, keahlian, nilai dan perilaku. Aset-aset ini tidak 
dimiliki oleh perusahaan tetapi penggunaan aset ini diakses melalui perekrutan karyawan perusahaan. Aset jenis ini disebeut sebagai modal manusia (human capital).

\section{Aset Struktur Internal}

Bagian ini menunjukkan bagian formal dan informal struktur organisasi, metode kerja dan prosedur, perangkat lunak (software), database, sistem penelitian dan pengembangan (R\&D system), sistem manajemen, dan budaya. Aset-aset ini dimiliki oleh perusahaan dan beberapa dapat dilindungi secara legal/hukum (patent, intellectual property dan lain-lain). Aset-aset ini disebut modal struktural (structural capital).

\section{Aset Struktur Eksternal}

Bagian ini untuk portofolio pelanggan perusahaan (yang sering disebut sebagai goodwill) dan hubungan dengan suplier, bank dan pemegang saham, perjanjian kerjasama dan persekutuan (strategic, teknologi, produksi, dan pemasaran), merk komersial dan image. Aset-aset ini dimiliki oleh perusahaan dan beberapa dapat di dilindungi secara legal/hukum seperti merk komersial dan lain-lain. Aset-aset ini disebut modal relasional (relational capital).

Bontis et al. (2000) memberikan perbandingan konsep intellectual capital dari beberapa penulis/peneliti seperti pada Tabel 2.

Petty (2009) menyatakan bahwa telah banyak pengukuran intellectual capital dan model pelaporan yang telah dikembangkan oleh akademisi, konsultan dan praktisi. Model popular yang digunakan untuk membangun laporan intellectual capital yaitu Kaplan dan Norton's Balance Scorcard (Kaplan and Norton 1992), Karl-Erik Sveiby Intangible Assets Monitor (Sveiby 1997), dan Sakndinavia's Value Schem (Edvinsson and Malone, 1997). Model-model tersebut diungkapkan dalam peneltian Petty (2009).

\section{Kinerja Keuangan dengan Ukuran Funda- mental}

Kinerja perusahaan sangat esensial bagi manajemen karena menghasilkan outcome yang telah dicapai baik oleh individu atau kelompok individu dalam suatu organisasi yang terkait dengan otoritas dan tanggung jawab dalam mencapai legalitas tujuan, bukan terhadap hukum dan mengkonfirmasi moral dan etik. Kinerja merupakan fungsi kemampuan organisasi untuk mencapai dan mengatur sumber-sumber daya perusahaan dalam cara yang berbeda untuk mengembangkan keunggulan bersaing.

Chen et al. (2005) menguji intellectual capital yang berasosiasi dengan kinerja keuangan perusahaan dan dapat menjadi indikator penting untuk kinerja masa depan perusahaan. Kinerja keuangan yang digunakan dalam penelitian tersebut adalah Returns on Equity (ROE), Returns on Assets (ROA), pertumbuhan penjualan bersih dan nilai tambah bersih per karyawan/produktivitas karyawan. ROE menunjukkan pengembalian ke pemegang saham atas saham biasa dan umumnya dipertimbangkan sebagai indikator keuangan penting bagi investor. ROA mencerminkan

Tabel 2. Perbandingan Konseptual Intellectual Capital beberapa Penulis

\begin{tabular}{|c|c|c|c|}
\hline Annie Brooking (U.K) & Goran Roos (U.K) & Thomas Stewart (U.S.A) & Nick Bontis (Canada) \\
\hline $\begin{array}{l}\text { Human-Centred Assets } \\
\text { Keterampilan, kemampuan } \\
\text { dan keahlian, kemampuan } \\
\text { memecahkan masalah dan } \\
\text { gaya kepemimpinan }\end{array}$ & $\begin{array}{l}\text { Human Capital } \\
\text { Kompetensi, perilaku dan } \\
\text { kecerdasan intelektual }\end{array}$ & $\begin{array}{l}\text { Human Capital } \\
\text { Karyawan adalah asset } \\
\text { terpenting organisasi }\end{array}$ & $\begin{array}{l}\text { Human Capital } \\
\text { Pengetahuan tingkat } \\
\text { individu yang dimiliki } \\
\text { masing-masing individu }\end{array}$ \\
\hline $\begin{array}{l}\text { Infrastructure Assets } \\
\text { Seluruh teknologi, proses } \\
\text { dan metodologi yang } \\
\text { memampukan perusahaan } \\
\text { untuk berfungsi }\end{array}$ & $\begin{array}{l}\text { Organisational Assets } \\
\text { Seluruh organisasional, inovasi, } \\
\text { proses, property intelektual, } \\
\text { dan asset kultural }\end{array}$ & $\begin{array}{l}\text { Structural Capital } \\
\text { Pengetahuan yang melekat } \\
\text { dalam teknologi informasi }\end{array}$ & $\begin{array}{l}\text { Structural Capital } \\
\text { Aset bukan manusia atau } \\
\text { kapabilitas organisasional } \\
\text { yang digunakan untuk } \\
\text { memenuhi permintaan pasar }\end{array}$ \\
\hline Intellectual Propterty & $\begin{array}{l}\text { Renewal and Development } \\
\text { Capital }\end{array}$ & Structural Capital & Intellectual Propterty \\
\hline $\begin{array}{l}\text { Tahu-bagaimana, merek } \\
\text { dagang dan paten }\end{array}$ & $\begin{array}{l}\text { Paten-paten baru dan usaha- } \\
\text { usaha pelatihan }\end{array}$ & $\begin{array}{l}\text { Seluruh paten, rencana dan } \\
\text { merek dagang }\end{array}$ & $\begin{array}{l}\text { Tidak seperti IC, IP adalah } \\
\text { suatu aset yang dilindungi } \\
\text { dan memiliki definisi hukum }\end{array}$ \\
\hline $\begin{array}{l}\text { Market Assets } \\
\text { Merek, pelanggan, loyalitas } \\
\text { pelanggan dan saluran } \\
\text { distribusi }\end{array}$ & $\begin{array}{l}\text { Relational Capital } \\
\text { Hubungan termasuk internal } \\
\text { dan pemangku kepentingan } \\
\text { eksternal }\end{array}$ & $\begin{array}{l}\text { Customer Capital } \\
\text { Informasi pasar yang } \\
\text { digunakan untuk } \\
\text { menguasai seorang } \\
\text { pelanggan }\end{array}$ & $\begin{array}{l}\text { Relational Capital } \\
\text { Modal pelanggan adalah } \\
\text { hanya satu karakteristik } \\
\text { pengetahuan yang melekat } \\
\text { pada hubungan } \\
\text { organisasional }\end{array}$ \\
\hline
\end{tabular}


efisiensi perusahaan dalam menggunakan total aset. Pertumbuhan penjualan bersih mengukur perubahan pendapatan perusahaan. Peningkatan dalam pendapatan biasanya sinyal kesempatan perusahaan untuk bertumbuh. Nilai tambah bersih per karyawan/produktivitas karyawan mengukur nilai tambah bersih per karyawan yang mencerminkan produktivitas karyawan.

Firer and Williams (2003) menyatakan dimensi tradisional kinerja perusahaan terdiri dari 1) profitability, 2) productivity, dan 3) market valuation. Dimensi profitability merupakan tingkat yang menggambarkan kelebihan pendapatan diatas beban suatu perusahaan. Dimensi productivity adalah produktivitas perusahaan atau efisiensi perubahan input menjadi output. Dimensi market valuation secara konvensional diterima sebagai nama atau label yang sering disebut sebagai penilaian pasar. Secara prinsip, pendapat tradisional menyatakan kinerja perusahaan adalah pengembalian keuangan untuk pemilik perusahaan dari konsumsi sumber-sumber daya berwujud. Alternatifnya, pendapat-pendapat teori saat ini menyarankan investor, karyawan, supplier, pelanggan dan stakeholders relevan lainnya (seperti pemerintah) berkontribusi dan menerima keuntungan dari suatu perusahaan (Turnbull, 1997). Ukuran tradisional terus berlanjut mendominasi pentingnya menentukan keberadan setiap ukuran yang mungkin secara instrinsik menangkap kontribusi dari sumbersumber daya intellectual capital seperti human resources, customer reputation, serta research and development.

Analisis fundamental bisnis meliputi analisa laporan keuangan dan kesehatan organisasi, keuntungan bersaing dan keuntungan manajemen, pesaingnya dan pasar. Ketika diterapkan di masa mendatang fokusnya dalam keseluruhan keadaan ekonomi, tingkat bunga, produksi, laba dan manajemen. Analisis fundamental dibentuk melalui data historis dan data saat ini, tetapi dengan tujuan membuat peramalan keuangan. Beberapa tujuan penggunaan analisis fundamental yaitu: 1) untuk melakukan penilaian saham perusahaan dan memprediksi kemungkinan evolusi harga saham, 2) untuk membuat proyeki kinerja perusahaan, 3) untuk mengevaluasi manajemen dan membuat keputusan bisnis internal dan 4) untuk menghitung risiko kredit. Penelitian ini menggunakan analisis fundamental profitability dan productivity untuk mengukur kinerja perusahaan.

\section{Intellectual Capital dan Kinerja Keuangan Perusahaan}

Banyak penulis sangat percaya bahwa intellectual capital memiliki hubungan positif dengan kinerja keuangan perusahaan (Riahi-
Belkaoui 2003, Youndt et al. 2004, Chen et al. 2005, Tan et al. 2007 dalam Zéghal dan Maaloul 2010). Chen et al. 2005 dalam Zéghal dan Maaloul 2010 menyatakan intellectual capital merupakan sumber daya yang bernilai untuk keuntungan bersaing perusahaan dan akan dikontribusikan di dalam kinerja keuangan perusahaan. Tan et al. (2007) dalam Zéghal dan Maaloul (2010) menyatakan bahwa intellectual capital mendorong perusahaan lebih bersaing dibandingkan dengan perusahaan lainnya dan lebih sukses.

Meningkatnya kepentingan dalam akuntansi untuk aset tidak berwujud dalam neraca telah meningkatkan kekuatiran dalam menghasilkan informasi yang menyesatkan. Pendukung yang beragam sistem akuntansi untuk intellectual capital menyatakan terdapat perbedaan penjelasan antara nilai buku dan nilai perusahaan. Beberapa profesional akuntansi berpendapat tentang penyertaan aset tidak berwujud dalam Neraca karena: a) banyak aset yang tidak dimiliki dan dikendalikan oleh perusahaan dan b) terfokus pada etika untuk memasukkan modal manusia dalam Neraca menempatkan harga untuk menilai manusia dan kuantifikasi nilai karyawan berisiko karena dapat memberikan kesan karyawan, distubtitusikan dalam bentuk modal lainnya.

Rehman et al. (2011) mengekplorasi berbagai penentu intellectual capital dan pengaruhnya pada kinerja keuangan sektor asuransi di Pakistan. Kinerja intellectual capital diukur dengan model Value Added Intellectual Coefficient (VAIC TM) sedangkan kinerja keuangan menggunakan ukuran Return on Equity (ROE), Return on Invesment (ROI) dan Earnings per Share (EPS). Rehman, Rehman dan Zahid (2011) menguji kinerja intellectual capital pada perusahaan non laba (modaraba companies) dan pengaruhnya terhadap kinerja perusahaan dengan menggunakan ukuran Return on Equity (ROE), Return on Invesment (ROI) dan Earnings per Share (EPS).

Bontis (2000) menguji intellectual capital dan kinerja bisnis di industri malaysia. Zéghal dan Maaloul (2010) menganalisa peran value added (VA) sebagai indokator intellectual capital dan pengaruhnya dalam ekonomik perusahaan, keuangan dan kinerja pasar saham. Penelitian ini mengukur intellectual capital berdasarkan market to book value. Chen et al. (2005) menginvestigasi secara empiris hubungan antara efisiensi penciptaan nilai, penilaian pasar perusahaan dan kinerja keuangan.

Penelitian ini mengukur intellectual capital berdasarkan market to book value. Keuntungan metode ini adalah (Iswati dan Anshori 2007): a) informasi untuk menghitung intellectual capital disiapkan untuk publik, b) sesuai untuk keputus- 
an manajemen dan 3) sesuai untuk pengguna eksternal karena indikator yang digunakan secara umum diketahui dan informasi yang mudah untuk diperoleh.

Market-to-book value merupakan ukuran eksternal (Shaikh 2004). Nilai intellectual capital umumnya diekspresikan sebagai perbedaan antar nilai pasar dan nilai buku perusahaan. Dari perspektif internal, perbedaan antara nilai pasar dan nilai buku, utamanya untuk aset saat ini tidak dimasukkan dalam Neraca seperti pengetahuan, hubungan dan citra. Dari sisi perspektif eksternal, perbedaan nilai pasar dan nilai buku umumnya menggambarkan kesempatan masa depan perusahaan dan item ini tidak dinilai di dalam Neraca.

Kinerja keuangan perusahaan difokuskan pada profitability (Walker, 2001) yang diproksikan oleh EBIT, dengan alasan sebagai berikut:

- Implementasi laba bersih sebelum pajak mengeliminasi pengaruh perubahan struktur pajak untuk level profitability.

- Mengidentifikasi keefektifan perusahaan dalam mengelola sumber-sumber daya.

Kinerja perusahaan difokuskan pada productivity yang diproksikan oleh Asset Turnover karena ukuran ini mencerminkan bagaimana aset perusahaan menghasilkan pendapatan; mengindikasikan volume bisnis yang dihasilkan oleh dasar aset (yaitu arus pendapatan melalui aliran aset). Berdasarkan kajian literatur yang telah dijelaskan sebelumnya, maka hipotesis dalam penelitian ini:

Hipotesis: intellectual capital mempengaruhi kinerja keuangan perusahaan.

\section{METODE PENELITIAN}

Penelitian ini akan menguji pengaruh intellectual capital terhadap kinerja keuangan perusahaan berdasarkan ukuran fundamental perusahaan. Penelitian ini menggunakan paradigma kuantitatif. Untuk menguji hipotesis menggunakan analisis regresi berganda linear. Penelitian akan menguji intellectual capital menggunakan ukuran eksternal yaitu market-to-book value (Shaikh, 2004). Kinerja keuangan perusahaan diukur dengan menggunakan EBIT sebagai ukuran profitability (Iswati dan Anshori, 2007) dan Asset Turnover sebagai ukuran productivity (Firer and Williams, 2003)

Penelitian ini menganalisis hubungan antara dependent variable dan independent variable. Definisi masing-masing adalah sebagai beirkut: a. Kinerja Keuangan Perusahaan (KP) sebagai dependent variable

Kinerja keuangan perusahaan diukur dengan profitability yang diproksikan oleh EBIT dan productivity yang diproksikan oleh assets turnover (AT). Variabel ini menggambarkan ukuran keefektifan pengukuran aset.

b. Intellectual Capital (IC) sebagai independent variable

Ukuran intellectual capital adalah nilai pasar yang melebihi nilai aset berwujud dalam Neraca. Intellectual capital ditentukan dengan rumusan market-to-book value (Shaikh, 2004 dan Stewart, 2002). Penelitian ini juga menggunakan variabel kontrol yaitu ukuran perusahaan (size) yang diproksikan jumlah karyawan dan jenis industri dengan menggunakan dummy variabel yang menyajikan tiga jenis industi dalam sektor jasa. Industri jasa memerlukan banyak tenaga kerja dalam menjalan aktivitas perusahaan dibandingkan dengan kebutuhan aset fisik. Perusahaan sektor ini mengindikasikan bahwa intellectual capital menentukan kualitas jasa perusahaan yang akan diberikan ke pelanggan.

Penelitian ini menggunakan populasi dari perusahaan yang terdaftar di Bursa Efek Indonesia untuk jenis industri: 1) Bank; 2) Asuransi; dan 3) Jasa. Jenis ke tiga industri tersebut dipilih sebagai sampel penelitian dikarenakan tingkat kemampuan dan kualitas sumber daya manusia diperlukan dalam berlangsungnya kinerja keuangan perusahaan. Sumber daya manusia di sektor bank, asuransi dan jasa lebih banyak berkomunikasi langsung dengan pelanggan dalam menjual produk perusahaan. Oleh karena itu, keberlangsungan perusahaan sangat tergantung dengan kemampuan masing-masing individu dalam menjual produk perusahaan. Sampel dalam penelitian ini adalah perusahaan dengan periode fiskal yang sama. Dari tahun pengamatan, ke tiga jenis industri yang digunakan dalam penelitian ini berjumlah 66 perusahaan. Sebanyak 25 perusahaan tidak dapat digunakan dikarenakan ketidak ketersediaan data yang diperlukan dalam penelitian ini sehingga jumlah akhir yang diperoleh sebanyak 41 sampel.

Untuk menguji hipotesis pada penelitian ini digunakan data sekunder berupa laporan keuangan yang diperoleh dari website Bursa Efek Indonesia dan Indonesian Capital Market Directory. Laporan keuangan yang dibutuhkan adalah tahun 2008 untuk data kinerja perusahaan, sedangkan untuk mengukur intellectual capital menggunakan laporan keuangan dari tahun 2004-2008. 
Tabel 3. Deskripsi Sampel

\begin{tabular}{lll}
\hline No & Jenis Industri & Jumlah \\
\hline 1. & Bank & 17 \\
2. & Asuransi & 10 \\
3. & Jasa & 14 \\
& Total Sampel & $\mathbf{4 1}$ \\
\hline
\end{tabular}

Penelitian ini akan menguji intellectual capital yang menggunakan ukuran eksternal perusahaan yaitu nilai pasar. Tujuan penelitian ini menggunakan ukuran eksternal perusahaan untuk melihat respon pasar terhadap kinerja perusahaan yang diproksikan oleh EBIT (laba sebelum pajak) dan AT (perputaran aset). EBIT digunakan karena respon pasar yang baik dapat mempengaruhi kinerja perusahaan dalam hal ini adalah laba. AT digunakan karena item ini menunjukkan produktivitas penggunaan aset. Kedua instrumen ini menggambarkan ukuran keefektifan pengukuran aset.

Hipotesis dalam penelitian ini akan diuji dengan menggunakan regresi berganda. Model analisis yang digunakan dalam penelitian ini adalah:

$$
\text { KP: 1) } \mathrm{EBIT}=\mathrm{a}_{0}+\mathrm{a}_{1} \mathrm{IC}+\mathrm{a}_{2} \mathrm{Size}+\mathrm{a}_{3} \mathrm{As}+\mathrm{a}_{4} \mathrm{Js}
$$$$
\text { 2) } \mathrm{AT}=\mathrm{a}_{0}+\mathrm{a}_{1} \mathrm{IC}+\mathrm{a}_{2} \mathrm{Size}+\mathrm{a}_{3} \mathrm{As}+\mathrm{a}_{4} \mathrm{JS}
$$

Keterangan:

$\mathrm{KP}=$ kinerja keuangan perusahaan yang diproksikan oleh EBIT dan AT

$\mathrm{EBIT}=$ laba bersih sebelum pajak

$\mathrm{AT}=$ pendapatan kotor dibagi dengan total aset

Kinerja keuangan perusahaan yang diproksikan oleh EBIT dan AT akan diuji dua kali persamaan regresi dengan dependen variabel EBIT dan persamaan regresi berikutnya menggunakan dependen variabel AT.

IC $\quad=$ (rata-rata lima tahun nilai pasar rata-rata lima tahun nilai buku)

Nilai Pasar = harga per lembar saham $\mathrm{X}$ dari saham beredar

Size $\quad=$ umlah karyawan

As $\quad$ dummy variabel untuk perusahaan i dikodekan 1 jika dari industri asuransi; lainnya 0 .

Js = dummy variabel untuk perusahaan i dikodekan 1 jika dari industri jasa; lainnya 0 .

\section{HASIL PENELITIAN DAN PEMBAHASAN}

Untuk menguji pengaruh intellectual capital terhadap kinerja perusahaan penelitian menggunakan lima (5) tahun untuk proksi intellectual capital dan satu (1) tahun untuk proksi kinerja perusahaan. Hipotesis pada penelitian ini diuji menggunakan regresi berganda. Berikut data deskriptif statistik untuk varibel yang digunakan dalam penelitian ini.

Tabel 4. Deskripsi Statistik

\begin{tabular}{llllll}
\hline & N & Minimum & Maximum & Mean & Std. Deviation \\
\hline EBIT & 41 & -28018 & 8822012 & 899051.85 & 2174095.744 \\
AT & 41 & 00 & 6.85 & 8107 & 1.39757 \\
IC & 41 & -1 & 4 & 1.53 & 1.043 \\
SIZE & 41 & 2 & 37484 & 4618.15 & 9142.343 \\
Valid N & 41 & & & & \\
(listwise) & & & & \\
\hline
\end{tabular}

Tabel 4 menggambarkan deskripsi statistik untuk masing-masing variabel yang digunakan untuk menguji pengaruh intellectual capital terhadap kinerja keuangan perusahaan. Dari tabel di atas menunjukkan bahwa rata-rata EBIT sebesar Rp 899.051,85; AT sebesar 0,8107; IC sebesar 1,53 dan SIZE sebesar 4.618 karyawan. Pertama akan menguji model regresi dengan proksi kinerja keuangan perusahaan EBIT. Penelitian ini telah memenuhi uji asumsi klasik.

Tabel 5. Hasil Pengujian

\begin{tabular}{ll}
\hline $\mathrm{R}$ & $.632^{\mathrm{a}}$ \\
$\mathrm{R}$ Square & .400 \\
Adjusted R Square & .333 \\
(Constant) & -2923859 \\
As & 216695.2 \\
$\mathrm{Js}$ & -216292 \\
\hline
\end{tabular}

Dari Tabel 5 menunjukkan diperolehnya nilai $\mathrm{R}^{2}=0,400$ yang artinya variabel intellectual capital, size dan jenis industri dapat menerangkan variabilitas sebesar $40 \%$ dari variabel kinerja perusahaan (EBIT) sedangkan sisanya diterangkan oleh variabel lain. Tabel 5 juga menunjukkan variabel kontrol yaitu jenis industri menunjukkan bahwa EBIT industri asuransi lebih besar 216.695,5 dibandingkan dengan bank, dan EBIT industri jasa lebih rendah 216.292 dibandingkan dengan bank.

Tabel 6. Hasil Uji Regresi

\begin{tabular}{lcrcrr}
\multicolumn{6}{c}{ ABOVA $^{\mathrm{b}}$} \\
\hline Model & $\begin{array}{c}\text { Sum of } \\
\text { Squares }\end{array}$ & $\begin{array}{c}\text { df } \\
\text { Mean } \\
\text { Square }\end{array}$ & F & Sig. \\
\hline 1. Regression & $8 \mathrm{E}+013$ & 4 & $1.890 \mathrm{E}+013$ & 5.997 & $.001^{\mathrm{a}}$ \\
Residual & $1 \mathrm{E}+014$ & 36 & $3.152 \mathrm{E}+012$ & & \\
Total & $2 \mathrm{E}+014$ & 40 & & & \\
\hline a. Predictor: (Constant), Js, IC, AS, SIZE & \\
b. Dependent variable: EBIT & & & \\
\hline
\end{tabular}

Tabel 6 menunjukkan hasil pengujian regresi yang menunjukkan nilai signifikansi sebesar 0,001 $<0,05$ yang berarti bahwa $\mathrm{H}_{0}$ ditolak. Intellectual capital yang diproksikan oleh nilai pasar IC mempengaruhi kinerja keuangan perusahaan yang 
diproksikan oleh EBIT. Berikut merupakan pengujian kedua dengan kinerja perusahaan yang diproksikan dengan AT. Regresi yang ke dua dengan variabel AT sebagai variabel dependen telah dilakukan uji asumsi klasik.

Tabel 7. Hasil Pengujian

\begin{tabular}{ll}
\hline $\mathrm{R}$ & $.590^{\mathrm{a}}$ \\
$\mathrm{R}$ Square & .348 \\
Adjusted R Square & .276 \\
(Constant) & -1.517 \\
As & 1.035 \\
$\mathrm{Js}$ & 2.274 \\
\hline
\end{tabular}

Tabel 7 menunjukkan diperolehnya nilai $\mathrm{R}^{2}=$ 0,348 yang artinya variabel intellectual capital, size dan jenis industri dapat menerangkan variabilitas sebesar 34\% dari variabel kinerja perusahaan (AT) sedangkan sisanya diterangkan oleh variabel lain. Dari Tabel 7 juga menunjukkan variabel kontrol yaitu jenis industri menunjukkan bahwa AT industri asuransi lebih besar 103,5\% dibandingkan dengan bank, dan AT industri jasa lebih besar $227,4 \%$ dibandingkan dengan bank.

Tabel 8. Hasil Uji Regresi

\begin{tabular}{lccccc}
\multicolumn{6}{c}{ ABOVA $^{\mathrm{b}}$} \\
\hline Model & $\begin{array}{c}\text { Sum of } \\
\text { Squares }\end{array}$ & $\mathbf{d f}$ & $\begin{array}{c}\text { Mean } \\
\text { Square }\end{array}$ & F & Sig. \\
\hline 1. Regression & 27.193 & 4 & 6.798 & 4.805 & $.003^{\mathrm{a}}$ \\
Residual & 50.935 & 36 & 1.415 & & \\
Total & 78.128 & 40 & & & \\
\hline a. Predictor: (Constant), Js, IC, AS, SIZE & \\
b. Dependent variable: AT \\
\hline
\end{tabular}

Tabel 8 menunjukkan hasil pengujian regresi yang menunjukkan nilai signifikansi sebesar 0,003 $<0,05$ yang berarti bahwa $\mathrm{H}_{0}$ ditolak. Intellectual capital yang diproksikan oleh nilai pasar IC mempengaruhi kinerja keuangan perusahaan yang diproksikan oleh AT.

Hasil pengujian empiris menemukan adanya pengaruh intellectual capital terhadap kinerja keuangan perusahaan yang diproksikan oleh EBIT dan AT. Intellectual capital yang menyangkut pengetahuan yang melekat pada individu menunjukkan adanya pengaruh terhadap kinerja keuangan perusahaan. Ukuran fundamental digunakan dalam penelitian ini untuk mengukur kinerja keuanganperusahaan menggunakan ukuran profitabilitas yang diproksikan dengan EBIT dan produktivitas aset yang diproksikan dengan asset turnover (AT).

Ukuran intellectual capital dalam penelitian ini menggunakan nilai pasar yaitu market-to-sbook value. Pada saat perusahaan melakukan akuisisi, harga yang dibayarkan untuk memperoleh perusahaan yang diakuisi pada umunya menunjuk- kan nilai pasar yang lebih besar dibandingkan dengan nilai buku perusahaan. Perbedaan nilai pasar dan nilai buku tersebut menunjukkan adanya goodwill yang muncul dalam proses pemerolehan perusahaan yang tercatat dalam neraca perusahaan. Pada perspektif akuntansi konvensional, goodwill yang merupakan selisih nilai pasar dan nilai buku perusahaan merupakan aset yang meliputi pengetahuan, hubungan dan image. Perspektif lain menganggap bahwa selisih nilai pasar dan nilai buku merupakan kesempatan masa depan perusahaan yang saat ini belum dinilai dalam neraca perusahaan.

Ukuran fundamental perusahaan sering digunakan untuk mengukur kinerja keuangan perusahaan. Penelitian ini menggunakan EBIT dan AT. EBIT dapat digunakan untuk mengukur laba yang dihasilkan perusahaan. Respon pasar yang baik dapat meningkatkan laba perusahaan. Profitability merupakan perhatian akuntansi dan keuangan yang bukan semata-mata berfokus pada pemilik perusahaan dalam bentuk moneter tetapi juga berkontribusi terhadap kesejahteraan berbagai stakeholders. AT menunjukkan produktivitas aset perusahaan. AT mengukur efisiensi perusahaan ketika menggunakan aset dalam menghasilkan pendapatan. Dalam menghasilkan pendapatan perusahaan untuk industri jasa bergantung pada sumber daya manusia dengan keahlian yang dimiliki individu tersebut, misal keahlian untuk bisa menjalin relasi dengan konsumen, pengetahuan produk perusahaan, dsb.

Hasil pengujian intellectual capital dengan menggunakan ukuran eksternal perusahaan yaitu nilai pasar mempengaruhi laba perusahaan dan produktivitas aset perusahaan. Sumber daya manusia sangat menentukan kinerja perusahaan dalam menghasilkan pendapatan dibandingkan dengan jenis industri lainnya. Jenis industri yang digunakan dalam penelitian ini ada bank, asuransi dan jasa seperti travel dan hotel, iklan, dsb. Sebagai variabel kontrol yaitu jenis industri menunjukkan bahwa EBIT industri asuransi lebih besar dibandingkan dengan bank, dan EBIT industri jasa lebih rendah dibandingkan dengan bank. Sedangkan untuk produktivitas asset menunjukkan bahwa AT industri asuransi lebih besar dibandingkan dengan bank, dan AT industri jasa lebih besar dibandingkan dengan bank.

Chen et al. (2005) menemukan hasil bahwa intellectual capital perusahaan memiliki pengaruh positif pada nilai pasar dan kinerja keuangan perusahaan, dan memungkinkan sebagai indikator kinerja keuangan masa depan perusahaan. Zéghal dan Maaloul (2010) menemukan asosiasi yang positif antara intelectual capital dengan menggunakan value added dengan kinerja ekono- 
mik dan kinerja pasar saham. Bontis et al. (2005) menyatakan bahwa hasil penelitiannya menunjukkan intelectual capital memiliki hubungan signifikan dan substantive dengan kinerja bisnis terhadap sektor industria.

\section{KESIMPULAN}

Intellectual capital pada perusahaan jenis industri jasa menunjukkan ada pengaruh dalam kinerja keuangan perusahaan. Ukuran internal dan eksternal dapat digunakan untuk mengukur intellectual capital (Shaihk 2004). Ukuran eksternal perusahaan digunakan pada penelitian ini untuk mengukur intellectual perusahaan yaitu market-to-book value. Pasar merespon kinerja keuangan perusahaan yaitu profitability dan produktivitas perusahaan yang diproksikan oleh EBIT dan AT. Beberapa tahun terakhir produkproduk asuransi mulai dikenal banyak masyarakat Indonesia yang sebelumnya mungkin belum terpikirkan sehingga masyarakat mulai sadar asuransi untuk berbagai hal. Untuk mengenalkan produk tersebut diperlukan sumber daya manusia yang harus memiliki keahlian khusus. Hal ini juga ditunjukkan dari hasil penelitian dimana profitability dan produktivitas aset industri asuransi lebih besar dibandingkan dengan industri lainnya yang digunakan dalam penelitian ini.

Keahlian atau kemampuan sumber daya manusia yang dimiliki perusahaan dapat tertuang di item goodwill ketika perusahaan melakukan akuisisi. Namun demikian untuk perusahaan yang tidak melakukan akuisisi, laporan tahunan perusahaan belum memasukkan keahlian atau kemampuan sumber daya manusia sebagai salah satu elemen dalam neraca walaupun intellectual capital lebih diidentikkan dengan intangible asset hal ini dikarenakan intellectual capital sulit untuk dikuantifikasikan. Perspektif lain menganggap bahwa perbedaan nilai pasar dan nilai buku menunjukkan kesempatan perusahaan di masa depan. Perusahaan menekankan bahwa intellectual capital merupakan hal penting untuk menuju sukses dalam menghadapi persaingan masa depan. Namun hal itu belum dapat diterjemahkan dalam suatu pesan yang solid dan koheren dalam laporan tahunan (Guthrie dan Pety 2000 dalam Sawarjuwono 2003)

\section{Keterbatasan dan Saran untuk Penelitian Selanjutnya}

Penelitian ini mempunyai beberapa keterbatasan yang sekaligus merupakan implikasi untuk penelitian selanjutnya:

a. Mengukur intellectual capital menggunakan ukuran eksternal lainnya, misal: Tobin's Q. b. Mengukur intellectual capital menggunakan ukuran internal, misal: The Skandinavian Navigator.

c. Menggunakan ukuran fundamental lainnya untuk mengukur kinerja perusahaan.

\section{DAFTAR PUSTAKA}

Bontis, N., Keow, W.C.C. \& Richardson, S. (2000), "Intellectual capital and business performance in Malaysian industries", Journal of Intellectual Capital, 1(1), page 85-100.

Chen, M-C, Cheng Shu-Ju and Hwang Y. (2005), "An Empirical Investigation of The Relationship Between Intellectual Capital and Firm's Market Value and Financial Performance", Journal of Intellectual Capital, Vol. 6, No. 2, page 159-170.

Firer, Steven and S. Mitchell Williams (2003), "Intellectual Capital and Traditional Measures of Corporate Performance", Journal of Intellectual of Capital, Vol. 4, No. 3, page 34860.

Hartono, Budi (2001), "Intellectual Capital: Sebuah Tantangan Akuntansi Masa Depan", Media Akuntansi, Edisi 2, Thn VIII, page 65-72.

Iswati, Sri dan Muslich Anshori (2007), "The Influence of Intellectual Capital to Financial Performance at Insurance Companies in Jakarta Stock Exchane (JSE)", Proceeding of the $13^{\text {th }}$ Asia Pacific Management Conference, Melbourne, Australia, page 1393-1399.

Marr, B. and G. Schiuma (2001), "Measuring and managing intellectual capital and knowledge assets in new economy organizations" Handbook of Performace Measurement, $M$ Bourne (ed), Gee, London.

Martî, Josẽ Maria Viedma (2003), "In Search of an Intellectual Capital General Theory", Electronic Journal on Knowledge Management, Volume 1 Issue 2, page 213-226.

McConnachie, Gordon (1997), "The Management of Intellectual Assets: Delivering Value to the Business", The Journal of Knowledge Management, 1 (1), 56-62.

Pety, R.M., Suresh Cuganesan, Nigel Finch and Guy Ford (22 Februari 2012), "Intellectual Capital and Valuation: Chalenges in the Voluntary Disclosure of Values Drivers, SSRN: http://ssrn.com/abstract $=1490208$ or http://dx.doi.org/10.2139/ssrn.1490208.

Rehman, W.U., Chaudhary Abdul Rehman and Ayesha Sahid (2011), "Intellectual Capital Performance and Its Impact on Corporate Performance: an Empirical Evidence from Modaraba Sector of Pakistan", Australian Journal of Business and Management Research, Vol. 1, No. 5, page 08-16. 
Rehman, W.U., Muhammad Ilyas and Hafeez ur Rehman (2011), "Intellectual Capital Performance and Its Impact on Financial Returns of Companies: An Empirical Study from Insurance Sector of Pakistan", African Journal of Business Management, Vol. 5, (20), page 80418049.

Sawarjuono, Tjiptohadi dan Agustine Prihatin Kadir (2003), "Intellectual Capital: Perlakuan, Pengukuran dan Pelaporan (Sebuah Library Research)", Jurnal Akuntansi \& Keuangan. Vol. 5, No. 1, page 35-57.

Shaikh, Junaid, M. (2004), "Measuring and Reporting of Intellectual Capital Performance Analysis", The Journal of American Academy of Business, Cambridge. March.

Stewart, A.T. (1997), "Intellectual Capital, The New Wealth of Organizations", New York: Bantam Doubleday Publishing.

Stewart, Thomas A. (2002), Modal Intelektual: Kekayaan Baru Organisasi, Jakarta: PT Elex Media Komputindo.
Turnbull, S. (1997), ”Corporate Governance: "Its Scope, Concerns and Theories", Corporate Governance: An International Review, Vol. 5 Iss. 4, page 180-205.

Walker, Dana Charle (20 Februari 2012), "Exploring the Human Capital Contribution to Productivity; Profitability; and the Market Evaluation of the Firm", http:/wwwlib.umi. com/dissertation/preview_all/3010003.

Zéghal, Daniel dan Maaloul (2010), “Analysing Value Added as an indicator of intellectual capital and its consequences on company performance", Journal of Intellectual Capital; Vol. 11, No. 1, page 39-60.

Zerenler, M., Selcuk Burak Hasiloglu, and Mete Sezgin (2008), "Intellectual Capital and Innovation Performance: Empirical Evidence in the Turkish Automotive Supplier", Journal of Technology Management and \& Innovation; Vol. 3, Issue 4, page 31-40. 